\title{
[EUGENIUSZ QUIRINI DE SAALBRÜCK], KIRKCALDY. POLSKA GWIAZDKA W SZKOCJI W 1940 ROKU
}

\section{Danuta Quirini-Popławska}

Uniwersytet Jagielloński w Krakowie http://orcid.org/0000-0002-4141-7617

\section{ABSTRACT}

This text is an edited source material that is a part of the memoirs of Certified Colonel Eugeniusz Quirini de Saalbrück (1891-1978) from his stay in Scotland in his capacity as a cultural and educational officer in the Polish soldiers camp in Kirkcaldy during World War II. The text is an account of a Christmas celebration organised for Scottish children on 19 December 1940 under the supervision of Col. Quirini in the local Rio cinema. The original text is part of Col. Quirini's estate that is in the possession of his family.

Keywords: Quirini de Saalbrück, Kirkcaldy, Scotland, Command of the Polish Camps and Units of the Polish Armed Forces in Scotland, cultural and educational activity of the Polish Army, World War II.

Słowa kluczowe: Quirini de Saalbrück, Kirkcaldy, Szkocja, Dowództwo Obozów i Oddziałów Wojska Polskiego w Szkocji, działalność kulturalno-oświatowa Wojska Polskiego, druga wojna światowa.

\section{WPROWADZENIE}

Autorem niniejszego wspomnienia jest Eugeniusz Quirini de Saalbrück (18911978), pseudonim „Włoch”, dyplomowany pułkownik Wojska Polskiego, słuchacz Wyższej Szkoły Realnej we Lwowie, Wydziału Budownictwa Dróg i Mostów Politechniki Lwowskiej, Wyższej Szkoły Wojennej oraz Uniwersytetu w Cambridge,

${ }^{1}$ Autorka edycji źródłowej pragnie wyrazić słowa podziękowania redaktorowi i recenzentom „Prac Historycznych” za wprowadzenie do tekstu cennych uwag i wskazówki, które podniosły wartość niniejszego opracowania.

Adres do korespondencji: danquirpop@poczta.onet.pl 
członek tajnej organizacji Armia Polska we Lwowie (1911) oraz Polskich Drużyn Strzeleckich (PDS). Wraz z IV Drużyną PDS z Kleparowa, której był organizatorem i instruktorem, 3 sierpnia 1914 roku wyruszył do Krakowa, gdzie wstapił do Legionów Polskich. Został skierowany do 3. Pułku Piechoty II Brygady Legionów Polskich i wziął udział we wszystkich jej kampaniach: karpackiej, besarabskiej, bukowińskiej i wołyńskiej². W październiku 1918 roku awansowany do stopnia porucznika. Po wybuchu wojny polsko-bolszewickiej od marca 1919 roku walczył na Polesiu w składzie 34. Pułku Piechoty, a następnie został mianowany kolejno szefem sztabu grupy operacyjnej, wchodzącej w skład XVIII Brygady Piechoty, dowodzonej przez płk. Aleksandra Jerzego Narbutt-Łuczyńskiego, oraz szefem sekcji w Oddziale I (Operacyjnym) Naczelnego Dowództwa Wojska Polskiego. Do przewrotu majowego odniósł się negatywnie, co walnie przyczyniło się do załamania jego kariery wojskowej. Po awansie do stopnia majora w 1924 roku (ze starszeństwem od 1 lipca 1923 r.) do czasów II wojny światowej nie awansował. W latach 1928-1932 pełnił obowiązki szefa Wojskowego Instytutu Naukowo-Wydawniczego, a następnie piastował funkcję zastępcy szefa tej instytucji, był redaktorem czasopism „Bellona” i „Wiarus”, publikował albumy, opracowania i wspomnienia dotyczące tematyki legionowej oraz wyszkolenia wojskowego. Tłumaczył też dzieła zagranicznych autorów dotyczące ważnych wydarzeń historycznych oraz artykuły opisujące stosowane na Zachodzie najnowocześniejsze taktyki dowodzenia i walki broni połączonych33 $\mathrm{Z}$ dniem 31 grudnia 1935 roku został przeniesiony w stan spoczynku.

Zmobilizowany we wrześniu 1939 roku, wziął udział w kampanii wrześniowej, uczestnicząc w przygotowaniach do obrony Warszawy. 5 września 1939 roku został odkomenderowany do Biura Propagandy Naczelnego Wodza, na którego czele stał ppłk Roman Umiastowski'; przejął równocześnie tzw. referat niemiecki, zajmując się w nim sporządzaniem aktualnych komunikatów z frontu niemieckiego. 18 września $^{5}$ wraz z kolumną rządową przekroczył granicę w Kutach i znalazł się na terenie Rumunii. Tam wraz z wieloma innymi Polakami był internowany aż do 26 grudnia 1939 roku. Następnie ruszył koleją przez Zagrzeb do Triestu. Po załatwieniu wszystkich formalności przejechał przez północne Włochy pociągiem, aby 31 grudnia 1939 roku dotrzeć do Francji. Tu 1 styczna 1940 roku zameldował się i został przyjęty do Stacji Zbornej dla Żołnierzy Polskich w koszarach Bessières w Paryżu ${ }^{6}$. Po ukonstytuowaniu

${ }^{2}$ H. Korczyk, Quirini de Saalbrück Eugeniusz [w:] Polski Stownik Biograficzny, t. 29, WrocławWarszawa-Kraków-Gdańsk-Lódź 1986, s. 532.

${ }^{3}$ Centralne Archiwum Wojskowe w Warszawie, AP 8, Wyciągi z rozkazów wewnętrznych m.in. Dowództwa Okręgu Korpusu II w Lublinie oraz listy kwalifikacyjne od 1924 do 1939 r.

${ }^{4}$ Zbiory prywatne E. Quiriniego (w posiadaniu Rodziny) [dalej: Zbiory...], Zaświadczenie L. dz. 27/39 Szefa Propagandy Naczelnego Wodza ppłk. dypl. Romana Umiastowskiego, Warszawa, dnia 5 IX $1939 \mathrm{r}$.

${ }^{5}$ Ibidem, E. Quirini Kalendarzyk Terminowy na rok 1939. Tam też codzienne notatki z trasy przejazdu do Rumunii łącznie z informacjami o miejscach noclegu.

${ }^{6}$ Ibidem, Certificat (zaświadczenie) nr 3460 wydane przez Centre d'Hebergement pour les Militares Polonais a Paris (Stacja Zborna dla Żołnierzy Polskich w Paryżu) z dnia 1 I 1940 r.; M. S zczurowski, Geneza formowania Armii Polskiej we Francji 1939-1940, „Piotrkowskie Zeszyty Historyczne”, t. 4, 2002, s. 122. 
się polskich władz na uchodźstwie ministrem spraw wojskowych oraz Wodzem Naczelnym Polskich Sił Zbrojnych został mianowany gen. dyw. Władysław Sikorski. W Ministerstwie Spraw Wojskowych w Paryżu utworzono wówczas Wydział Propagandy i Oświaty, który podlegał bezpośrednio pierwszemu wiceministrowi gen. dyw. Marianowi Kukielowi, wybitnemu historykowi wojskowości, posiadającemu równocześnie duże doświadczenie liniowe 7 . Szefem wydziału został ppłk Janusz Sopoćko ${ }^{8}$. Wydział składał się z dwóch referatów. Kierownikiem referatu propagandy został mianowany mjr Edward Ligocki ${ }^{9}$, a kierownikiem referatu oświaty mjr Eugeniusz Quirini ${ }^{10}$. W kwietniu 1940 roku mjr Quirini otrzymał przydział służbowy do Stacji Zbornej Oficerów w Camp de Carpiagne koło Marsylii, gdzie do czerwca 1940 roku pełnił funkcję referenta kulturalno-oświatowego.

Sytuacja polskich oddziałów przebywających na terenie Francji (około 85 tys. żołnierzy) po jej kapitulacji 17 czerwca oraz podpisaniu niemiecko-francuskiego układu o zawieszeniu broni 22 czerwca 1940 roku $^{11}$ była niezwykle trudna. Jeszcze tego samego dnia gen. Sikorski wydał rozkaz, aby Polskie Siły Zbrojne przebywające na terenie Francji kierowały się do portów, położonych na jej zachodnim wybrzeżu. Równocześnie spotkał się w Bordeaux z nowym premierem francuskim, marszałkiem Philippe Pétainem ${ }^{12}$, którego poinformował, że bez względu na decyzje rządu francuskiego rząd polski oraz armia polska nie złożą broni i będą nadal kontynuować walkę wspólnie z Wielką Brytanią ${ }^{13}$. Pomimo nieprzyjaznej postawy Francuzów i odmowy udzielenia jakiejkolwiek pomocy w okresie między 19 a 25 czerwca z Francji wyjechało około 40 procent żołnierzy polskich ${ }^{14}$. Aby umożliwić

${ }^{7}$ M. Hułas, Goście czy intruzi? Rząd polski na uchodźstwie wrzesień 1939-lipiec 1943, Warszawa 1996, s. 163-164.

${ }^{8}$ W. Biegański, Wojsko Polskie we Francji 1939-1940, Warszawa 1967, s. 183; idem, Zaczęło się w Coëtquidan, Warszawa 1977, s. 97.

${ }^{9}$ Edward Ligocki - ur. 1887, zm. 1966 w Warszawie, pisarz, poeta, dyplomata, mjr dypl. WP, po klęsce wrześniowej we Francji, po jej kapitulacji ewakuował się do Wielkiej Brytanii, a następnie został oddelegowany do Szkocji. W 1941 r. mianowany oficerem oświatowym z siedzibą w Edynburgu do łączności z władzami polskimi na obczyźnie. Z. Bilek-Dąbrowska, Ligocki Edward [w:] Polski Stownik Biograficzny, t. 17, Warszawa 1972, s. 323-325.

${ }^{10}$ W. Biegańs ki, Zaczęto się..., s. 97; idem, Wojsko Polskie..., s. 183.

${ }^{11}$ Bardziej szczegółowo na ten temat: A. Marecki, Jak korzystać z doświadczeń wojennych, „Bellona” 1940, R. XXII, z. 1, s. 44 i n.; Die Wehrmacht - Der Freiheitskampf des grossdeutschen Volkes, hrsg. von K. Fischer, Berlin 1940, s. 271 i n., 302, 317; W. Biegański, Finat dziwnej wojny. Studium o kampanii francuskiej 1940, Warszawa 1970, s. 335-339; J. S moliński, Ewakuacja Wojska Polskiego do Wielkiej Brytanii w czerwcu 1940, Warszawa 1996, s. 5; J. Zuziak, Wysitek mobilizacyjno-organizacyjny Polskich Sit Zbrojnych na Zachodzie w drugiej wojnie światowej, „Piotrkowskie Zeszyty Historyczne" 2003, t. 5, s. 240.

12 J. S molińs ki, Wysiłek wojenny Polskich SiłZbrojnychna Zachodzie (1939-1945), „Niepodległość i Pamięćc" 2019, nr 4 (68), s. 98; idem, Koncepcje formowania i użycia Wojska Polskiego we Francji (wrzesień 1939- czerwiec 1940), „Niepodległość i Pamięć” 2017, nr 2 (58), s. 167-169.

${ }_{13}$ Idem, Ewakuacja..., s. 24-28, 36-37, 65-75; idem, Koncepcje..., s. 169; O. Terlecki, General Sikorski, Kraków 1981, s. 262 i n., 278; W. Bi egański, Wojsko Polskie..., s. 352; M. Bielak, Ewakuacja żolnierzy polskich z Francji do Wielkiej Brytanii i Afryki Pólnocnej w latach 1940-1941 [w:] Letnia Szkota Historii Najnowszej, Warszawa 2009, s. 13 (wersja elektroniczna w Bibliotece Cyfrowej IPN).

${ }_{14}$ W. Biegańs ki, Polskie Sity Zbrojne na Zachodzie 1939-1945, Warszawa 1990, s. 11. 
ich ewakuację do Wielkiej Brytanii, gen. Sikorski już 19 czerwca podjął rozmowy z premierem Winstonem Churchillem ${ }^{15}$, uzyskując ze strony rządu brytyjskiego zapewnienie o kontynuowaniu wspólnej walki z najeźdźcą niemieckim. Równocześnie zdecydowano o wysłaniu polskich („Batory” i „Sobieski”) oraz brytyjskich statków do portów francuskich w celu ewakuacji polskich żołnierzy ${ }^{16}$. Wkrótce potem rząd polski na uchodźstwie wstępnie porozumiał się z władzami brytyjskimi w sprawach współpracy w dziedzinie politycznej i wojskowej, a 18 lipca gen. Sikorski zwrócił się do polskich żołnierzy z zapewnieniem, że „wojnę prowadzić będziemy do końca i zawsze po stronie tych państw i narodów, które walczyły z naszym odwiecznym wrogiem Niemcami”. Jednocześnie jako zbrodnicze określił te wypowiedzi, które „dalszą walkę uważają za niecelową i prowadzą agitację za porozumieniem z Niemcami" "17. Wstępne rozmowy polsko-angielskie uprawomocniała podpisana 5 sierpnia 1940 roku w Londynie polsko-brytyjska umowa wojskowa regulująca status polskich żołnierzy przybywających do Angliii ${ }^{18}$. Równocześnie na mocy ustawy z 22 sierpnia 1940 roku (Allied Forces Act) władze brytyjskie nadały tworzącym się polskim siłom zbrojnym na terenie Zjednoczonego Królestwa takie same prawa, jakie posiadały jednostki Brytyjskiej Wspólnoty Narodów ${ }^{19}$.

Ewakuowane z Francji oddziały polskie były przez Brytyjczyków kierowane do Szkocji. Liczbę uratowanych polskich żołnierzy jedni badacze obliczają na 27614 osób, inni na około 25 tys. (gen. Marian Kukiel) lub 23 tys. (gen. Władysław Sikorski), z kolei Witold Biegański podaje liczbę 19 451, zaś Michael Peszke 17205 żołnierzy. Należy też zaznaczyć, że w obiegu naukowym funkcjonują jeszcze inne dane statystyczne. Polscy żołnierze mieli ochraniać około dwustukilometrowy odcinek wschodniego wybrzeża Szkocji, od zatoki Firth of Forth do miejscowości Montrose, w razie spodziewanego desantu sił niemieckich ${ }^{20}$. Początkowo zostali skierowani do

15 J. S molińs ki, Ewakuacja..., s. 22; Armia Polska i życie społeczne Polaków we Francji. Wrzesień 1939-czerwiec 1940, wybór i oprac. M. Drozdowski, J. S moliński, Warszawa 2001, s. 143.

16 J. S moliński, Działalność naczelnych władz wojskowych podczas ewakuacji wojska polskiego do Wielkiej Brytanii w czerwcu 1940 r., „Niepodległość i Pamięć” 1999, nr 6/2 (15), s. 222-228; W. Biegański, Wojsko Polskie..., s. 115; S. Komornicki, Z. Bielecki, W. Bigoszewska, A. Jońca, Wojsko Polskie 1939-1945. Barwa i Broń, Warszawa 1984, s. 32; O. Terlecki, op. cit., s. $282-300$.

${ }^{17}$ Rozkaz Naczelnego Wodza i ministra spraw wojskowych gen dyw. Władysława Sikorskiego, Londyn, 18 VII 1940 r. Cyt. za: Zbiory..., E. Quirini, Zbiór materiałów: dokumentów, rysunków, kopii artykułów z prasy angielskiej i polskiej oraz fotografii w księdze pt. Poland and Scotland [dalej: Zbiór materiałów...].

${ }^{18}$ Historia dyplomacji polskiej, t. 5, 1939-1945, red. W. Michowicz, Warszawa 1999, s. 175.

19 Z. Waw er, Polskie Sity Zbrojne na obczyźnie [w:] Polski wiek XX: II wojna światowa, Warszawa 2010, s. 229-230, 233; L. Kania, Stużba Sprawiedliwości Wojska Polskiego we Francji i w Wielkiej Brytanii (październik 1939-październik 1940), „Przegląd Historyczno-Wojskowy” 2014, t. 15 (66), s. 91-92; W. Biegańs ki, Polskie Sity Zbrojne..., s. 98; J. Zuziak, op. cit., s. 241; L. Kania, Dylematy wojskowejTemidy, https://pk.gov.pl/wp-content/uploads/2016/07/a9be4a06bd6354fd3d926d1330949802. pdf [dostęp: 23 IV 2020 r.]; Władystaw Sikorski (1881-1943), https://dzieje.pl/postacie/wladislawsikorski [dostęp: 2 V 2020 r.].

${ }_{20}$ Polskie Siły Zbrojne w drugiej wojnie światowej, t. II, Kompanie na obczyźnie, cz. I, Wrzesień 1939-czerwiec 1941, Londyn 1959, s. 233; Sprawozdanie gen. Sosnkowskiego z przebiegu ewakuacji 
trzech improwizowanych obozów pod namiotami w miejscowościach Biggar, Douglas oraz Crawford, gdzie utworzono Centralny Obóz Wyszkolenia ${ }^{21}$.

Eugeniusz Quirini po kapitulacji Francji 17 czerwca 1940 roku przybył pociągiem wraz z dużą grupą żołnierzy ze stacji Zbornej Oficerów w Camp de Carpiagne do Bayonne, skąd 21 czerwca 1940 roku wojskowym transportem dotarł do granicy francusko-hiszpańskiej. Tu w małym porcie Saint-Jean-de-Luz czekał na Polaków stojący na redzie MS „Batory”22, na pokładzie którego Quirini ewakuował się w dniach 21-23 czerwca z Francji do brytyjskiego portu Plymouth. Na początku lipca został odkomenderowany do Szkocji i przydzielony do służby kulturalno-oświatowej w tamtejszych polskich obozach wojskowych. Początkowo przebywał w obozie w Glasgow, potem w Crawford, a 29 sierpnia został przeniesiony do Peebles.

Polscy żołnierze byli wyczerpani fizycznie, potrzebowali odpoczynku, do tego doszło rozprzężenie dyscypliny, marazm oraz swego rodzaju otępienie. Musieli poradzić sobie z klęską 1939 roku i pozostawieniem swych rodzin w rękach wroga, odbudować poczucie własnej wartości oraz wzmocnić się psychicznie. Mieli za sobą zawikłane szlaki walk, tułactwa, internowania, czasem ucieczkę z niewoli. Teraz, w sprzyjających warunkach, polskie władze na uchodźstwie zaczęły odbudowywać struktury wojskowe z zamiarem kontynuowania walki zbrojnej. Konieczne było odpowiednie zaopatrzenie w broń oraz wsparcie materialne. Ewakuując się z Francji, polscy żołnierze nie mogli zabrać ze sobą ciężkiego sprzętu, a angielscy sojusznicy w 1940 roku nie dysponowali rezerwami uzbrojenia i wyposażenia wojskowego ${ }^{23}$.

W Szkocji Polacy spotkali się z życzliwym przyjęciem i zrozumieniem ze strony miejscowego społeczeństwa. 3 września 1940 roku słowa powitania skierował do polskich żołnierzy, marynarzy i lotników premier Churchill, zwracając uwagę na konieczność kontynuacji walki ze wspólnym wrogiem, „zanim nadejdzie dzień waszego powrotu do Ojczyzny”. 20 września do polskich żołnierzy skierował odezwę gen. Sikorski, z jednej strony podkreślając w niej życzliwość i gościnność Brytyjczyków, z drugiej zaś odwołując się do takich tradycyjnych wartości wyznawanych przez

WP do Wielkiej Brytanii w czerwcu 1940 roku [w:] J. Smoliński, Polskie Sity Zbrojne na Zachodzie 1939-1945, Warszawa 1997, s 132-135; idem, Ewakuacja..., s. 59; idem, Wysilek wojenny ..., s. 99100; W. Bieg ański, Wojsko Polskie..., s. 62; idem, Polskie Sity Zbrojne..., s. 98; Armia Polska i życie społeczne..., s. 77-89; S. Komornicki, Z. Bielecki, W. Bigoszewska, A. Jońca, op. cit., s. 33; M. Peszke, Polskie Sity Zbrojne na Zachodzie 1939-1946, Poznań 2014, s. 376 (autor ten wspomina, że niektóre oddziały polskie przed wejściem na pokład zostały rozbrojone); S. Strumph-Wojtkiewicz, Wbrew rozkazowi. Wspomnienia oficera prasowego 1939-1945, Warszawa 1972, s. 93-94.

${ }^{21}$ M. Kroto fil, Wojsko polskie w Szkocji podczas II wojny światowej [w:] Sity Zbrojne RP. Wybrane zagadnienia, red. M. Krotofil, R. Rybak, Toruń 2019. Praca tego autora liczy zaledwie dwie strony, a podkreślić trzeba, że problem działalności Polskich Sił Zbrojnych na terenie Szkocji podczas II wojny światowej jest bardzo słabo opracowany. Z. Wawer, op. cit., s. 231; W. Biegański, Wojsko Polskie..., s. 343-345; J. S molińs ki, Wysiłek wojenny..., s. 103; idem, Polskie Sity Zbrojne na Zachodzie..., s. 29.

22 J. Smoliński, Ewakuacja..., s. 60 (tam też na s. 70-71 tekst sprawozdania gen. M. Kukiela z ewakuacji wojsk polskich z Francji zawierający informację, że w nocy z 21 na 22 VI zostali załadowani na MS „Batory” i odpłynęli do Wielkiej Brytanii m.in. żołnierze ze Stacji Zbornej Carpiagne).

${ }^{23}$ Ibidem, s. 74; B. Miśkiewicz, Wojsko Polskie na tle europejskim, http://www.wbc.poznan.pl/ Content/39738/PDF/Wojsko\%20Polskie\%20na\%20tle\%20uropejskim..pdf [dostęp: 5 IX 2020 r.]. 
polskiego żołnierza, jak honor, prawość i wierność złożonej przysiędze ${ }^{24}$. Wszyscy doskonale zdawali sobie sprawę z tego, że znajdujące się w Szkocji oddziały trzeba będzie formować od podstaw. 27 lipca 1940 roku funkcję dowódcy Obozów i Oddziałów Wojska Polskiego w Szkocji objął gen. Kukiel. Z kolei 28 września Naczelny Wódz gen. Władysław Sikorski utworzył z jednostek stacjonujących w Szkocji I Korpus Polski, którego dowódcą został gen. Kukiel.

Na podstawie rozkazów gen. Kukiela z 24 i 29 sierpnia 1940 roku Eugeniusza Quiriniego mianowano kierownikiem Samodzielnego Referatu Propagandy i Oświaty w Sztabie Dowództwa Obozów i Oddziałów Wojska Polskiego w Szkocji z miejscem postoju początkowo w Obozie Oficerów w Peebles ${ }^{25}$. W połowie października 1940 roku został odkomenderowany w charakterze referenta do spraw kulturalno-oświatowych do obozu w Kirkcaldy (Oddział Wydzielony 7. Brygady Kadrowej Strzelców). Jego podstawowym zadaniem było utrzymanie dyscypliny wśród żołnierzy i rekrutów, kierowanie ich szkoleniem, prowadzenie z nimi zajęć oświatowo-kulturalnych, czyli kształtowanie ich na świadomych obywateli Rzeczypospolitej, zdających sobie w pełni sprawę z obowiązków względem państwa i narodu, a także z celów wojny oraz ideałów, o które walczy Polska. Podjęte przez niego działania miały umożliwić formowanie nowych struktur wojskowych przygotowanych do kontynuowania walki. Podkreślić trzeba, że w Wielkiej Brytanii znaleźli się nie tylko zawodowi żołnierze, ale także zmobilizowani w 1939 roku rezerwiści oraz wielu cywilów, którzy zdecydowali się na angielskiej ziemi włączyć do walki z niemieckim agresorem.

Równocześnie Polacy byli świadomi, że należało pracować nad utrzymaniem jak najlepszych stosunków z mieszkańcami Szkocji poprzez popularyzację wiedzy o dziejach i kulturze polskiej, wyjaśnianie zadań stojących przed sojusznikami w trakcie wojny oraz uświadamianie miejscowej ludności roli, jaką w zmaganiach z Hitlerem odgrywała dotąd Polska. Realizując te zadania, jeszcze w Peebles zaczęto opracowywać metody nawiązania łączności z miejscową ludnością. Pierwszym krokiem w celu realizacji tych zadań w obozie w Peebles było zorganizowanie 5 października 1940 roku żołnierskiego wieczoru muzycznego. W jego programie znalazło się wykonanie polskich historycznych pieśni wojskowych, występy chóru wojskowego oraz orkiestry I Brygady Strzelców, a także prezentacja polskich tańców ludowych m.in. krakowiaka, kujawiaka i mazurka ${ }^{26}$.

Po odkomenderowaniu do obozu w Kirkcaldy Quirini rozpoczął realizowanie zaplanowanych zadań kulturalno-oświatowych wśród żołnierzy (szkolenia wojskowe, kursy nauki języka angielskiego, wykłady z zakresu historii i kultury) w celu zapoznania ich z ówczesną sytuacją na frontach, a także wzmocnienia ducha walki

${ }^{24}$ Thumaczenie wystapienia Churchilla oraz tekst odezwy gen. Sikorskiego [w:] Zbiory..., E. Quirini, Zbiór materiałów..., s. 1; S. Strumph-Wojtkiewicz, op. cit., s. 105-108, 112-115.

${ }^{25}$ Rozkazy gen. dyw. M. Kukiela, East End [dzielnica Glasgow], 24 i 29 VIII 1940 r. cyt. za: Zbiory..., E. Quirini, Zbiór materiałów...; S. Komornicki, Z. Bielecki, W. Bigoszewska, A. Jońca, op. cit., s. 33, 55.

${ }^{26}$ Zbiory..., E. Quirini, Zbiór materiałów..., Program Żołnierskiego wieczorku muzycznego w Peebles 5 X $1940 \mathrm{r}$. 
oraz morale. Równocześnie dla mieszkańców Kirkcaldy urządzano rozmaite imprezy i wieczorki, przybliżające polską tradycję historyczną oraz folklor, w tym pokazy pieśni i tańca z udziałem wykonawców Teatru Polowego Wojska Polskiego „Lwowska Fala"27 (m.in. Włady Majewskiej, Miry Grelichowskiej, Wiktora Budzyńskiego). W tym celu przygotowywano specjalne występy opracowane $\mathrm{w}$ języku angielskim (m.in. 17 listopada oraz 1 i 7 grudnia 1940 r.) . $^{28}$. Nawet w tak trudnych chwilach polscy żołnierze nie zapomnieli o uczczeniu rocznicy powstania listopadowego. 8 grudnia 1940 roku zorganizowali uroczysty wieczór pt. Polska walczy, opracowując tzw. żywy obraz z ilustracją słowno-muzyczną (scene with verbal and musical illustration), w trakcie którego zaprezentowano m.in. Alegorię Polski ${ }^{29}$. Organizowane przedstawienia z udziałem polskich żołnierzy cieszyły się dużą popularnością, o czym świadczył fakt, że brało w nich udział wielu przedstawicieli miejscowej społeczności, a w szkockiej prasie pojawiały się bardzo pochlebne opinie. Wkrótce organizowane przez polskich żołnierzy imprezy artystyczne zostały wzbogacone o występy miejscowego zespołu szkockiego, kierowanego przez Waltera Hinksa ${ }^{30}$. Ponieważ organizacja tych wieczorów wiązała się z kosztami, na przykład wynajęciem odpowiedniego lokum (m.in. sal w kinie Rio lub w Olympia Arcade), zdecydowano, że będą na nie sprzedawane bilety. Dochód z imprez przeznaczano na Fundusz Oświaty Polskiego Żołnierza, jak i na ukazującą się w Kirkcaldy od listopada 1940 roku powielaną „Gazetkę Obozową"31.

${ }^{27}$ Lwowska Fala - popularna audycja rozrywkowa Polskiego Radia Lwów, nadawana początkowo pod nazwą Wesoła Niedziela, a od VII 1933 do 1938 r. pod nazwą Wesoła Lwowska Fala. Po wybuchu II wojny światowej cały zespół przekroczył granicę rumuńską, udając się najpierw do Francji, a po jej upadku do Wielkiej Brytanii. Członkowie zespołu zostali zmobilizowani i organizowali występy dla polskich żołnierzy. Autorem większości tekstów był Wiktor Budzyński, występowały zaś m.in. Włada Majewska i Mira Grelichowska. Zespół działał do 1946 r. Większość jego członków pozostała na uchodźstwie. J. S moliński, Lwowska Fala na wojennym szlaku (1939-1946), red. nauk. J. Gmitruk, T. Skoczek, Warszawa 2021.

${ }^{28}$ Zbiory..., E. Quirini, Zbiór materiałów..., Program: Żołnierski wieczór. Piosenki i tańce, Kirkcaldy 17 XI 1940; ibidem, Teksty artykułów publikowanych w miejscowym tygodniku „The Fife Free Press” z 23 XI 1940 r. oraz w wydawanym w Londynie „Dzienniku Polskim” (nr 131 i 132 z 11 i 12 XII 1940 r.). W obu tytułach prasowych zamieszczane były również fotografie z omawianych rewii żołnierskich.

${ }^{29}$ Ibidem, Program: Polish „November Uprise” [sic!] 29 XI, 1830-1940; ibidem, Anniversary celebration in „Rio Theatre” Kirkcaldy 8 XII 1940.

${ }^{30}$ Walter Hinks (1902-1964) - menadżer w branży rozrywkowej, z zawodu inżynier, od 1939 r. kierownik miejskiego kina Rio w Kirkcaldy. Aktywnie angażował się w działalność charytatywną oraz prowadził pracę duszpasterską, wspomagając m.in. polskich żołnierzy stacjonujących w mieście podczas II wojny światowej. Biography of 'Hinks Walter', https://movingimage.nls.uk/biography/10017 [dostęp: 6 VII 2020 r.].

${ }^{31}$ Zbiory..., E. Quirini, Zbiór materiałów... (tam program uroczystości składającej się z dwóch części: I. Poland is still Living oraz II. Poland is Fighting, a także teksty artykułów z 11 XII 1940 r. zamieszczonych w „The Kirkcaldy Times” i „The Fife Free Press”). 


\section{Edycja tekstu źródłowego}

\section{MASZYNOPIS (PRZED 1969 R.), ZBIORY PRYWATNE EUGENIUSZA QUIRINI (W POSIADANIU RODZINY)}

Z końcem czerwca 1940 r. po ewakuacji z Francji rozproszone oddziały polskie przybyły na różnych statkach do portów Wielkiej Brytanii. Następnie zostały one przewiezione do obozów pod namiotami w Szkocji, a w sierpniu rozmieszczone na kwaterach w różnych miejscowościach.

Oddział, do którego należałem, dostał postój w mieście Kirkcaldy (wym.: Kirkody) liczącym około 60 tys. mieszkańców, będącym stolicą hrabstwa (odpowiednika naszego powiatu) Fife. Kirkcaldy leży na wschodnim brzegu Szkocji przy zatoce Firth of Forth - mniej więcej naprzeciwko Edynburga. Jest to ładne, rozbudowane miasto znane jako centrum przemysłowe na europejską skalę produkcji różnego rodzaju wykładzin, w tym głównie modnego od początku XX wieku - linoleum. Niestety, podczas trwającej wojny na wyroby tego typu spadło zapotrzebowanie. Mieszkańcy zaczęli odczuwać skutki trwającej wojny, bowiem rząd wspierał inne, potrzebne wówczas gałęzie przemysłu.

Jako referent kulturalno-oświatowy oddziału stacjonującego w Kirkcaldy starałem się utrzymać jak najlepsze stosunki z mieszkańcami miasta i miejscowymi władzami, co mi się całkowicie udało. Od początku naszego przybycia do Kirkcaldy były organizowane różne spotkania dla miejscowej ludności, w tym przedstawienia, przybliżające polską historię, muzykę, tańce i stroje. Przygotowywali je i uczestniczyli w nich nie tylko stacjonujący [w mieście] polscy żołnierze, ale znajdujący się tutaj polscy cywile w tym wiele kobiet. Przy zbliżających się świętach Bożego Narodzenia powstała myśl wystawienia polskich jasełek dla Szkotów, którzy jako ewangelicy tych religijnych uroczystości nie znali. Do realizacji tego przedsięwzięcia potrzebne były trzy rzeczy, a to: fundusze, dokładne przygotowanie programu oraz zabezpieczenie dostosowanego do imprezy lokum. A właśnie dysponowałem pewną sumą pieniędzy (około 100 funtów) zebranych z poprzednich przedstawien dochodowych, natomiast zaplanowana impreza miała być bezpłatna i przeznaczona dla szkockich dzieci. W pierwszym rzędzie trzeba było znaleźć odpowiednie pomieszczenie z możliwością jego wynajęcia. W grę wchodziła sala znajdująca się w największym w mieście kinie Rio, dysponująca ponad 2 tysiącami miejsc. Następnie trzeba było przygotować kosztorys na realizację całej uroczystości, jej dokładny program oraz przydzielenie odpowiedniej ilości osób z powierzonymi im obowiązkami. Ponadto postanowiłem, że każde szkockie dziecko dostanie małą paczkę ze słodyczami oraz pamiątkowy obrazek. Po sporządzeniu kosztorysu i obliczeniu kosztów imprezy okazało się, że posiadane fundusze wystarczą na pokrycie wszystkich wydatków. W tej sytuacji cała impreza została dokładnie rozplanowana, role przydzielone i wszystkie przygotowania poczynione.

Mając rozpisany dokładny plan spotkania wraz ze szczegółami pokazującymi projekt przygotowania polskich jasełek, udałem się do burmistrza (provost) miasta 
p. Jamesa (Jakuba) Wilsona, skądinąd wielkiego przyjaciela Polaków. Był to starszy, kulturalny pan, bardzo miły i uczynny ${ }^{32}$. Przedstawiony przeze mnie projekt urządzenia imprezy świątecznej dla dzieci szkockich bardzo mu się spodobał, ale równocześnie się zapytał, kto poniesie koszty związane z jego organizacją. Gdy mu oświadczyłem, że to my je pokryjemy, nie mógł ukryć swego zdumienia. Powiedziałem mu wówczas, że nie przybyliśmy tu, aby zarabiać, ale zależy nam, aby utrzymać jak najlepsze stosunki z miejscowym społeczeństwem, które także w ten sposób może poznać polskie obyczaje i tradycje religijne. Dziękując mi na końcu spotkania, zapewnił mnie, że mogę liczyć na jego wszelką potrzebną pomoc.

Następnie udałem się do naczelnika miejscowych szkół, ich głównego dyrektora, pana Gregora MacGregora. Chodziło mi przede wszystkim o otrzymanie zgody na udział młodzieży w przedstawieniu, czego byłem pewien, jak również o sposób realizacji planowego przedsięwzięcia. Na miejscu zastałem zebranych kierowników wszystkich szkół podstawowych w Kirkcaldy dyskutujących nad organizacją planowanego spotkania. Głównym, jak się okazało, problemem był dylemat, jak rozdzielić będące do dyspozycji 2 tysiące miejsc, skoro ogólna liczba młodzieży szkolnej w mieście wynosiła około 10 tysięcy dzieci. Podkreśliłem wówczas, że chodzi tylko o dwie najmłodsze klasy, ale okazało się, że i tak liczą one około 3 tysiące dzieci. Wówczas zaproponowałem, aby te 2 tysiące miejsc rozdzielić na drodze losowania przeprowadzonego we wszystkich miejscowych szkołach. Projekt ten zgromadzeni przyjęli z entuzjazmem.

Następny problem, który należało wówczas rozwiązać, wiązał się z ustaleniem terminu spotkania. Ponieważ od 20 grudnia rozpoczynały się ferie świąteczne, szopka mogła się odbyć najpóźniej 19 grudnia i to najpóźniej o godzinie 14 po południu, aby nie przeszkadzać w normalnym funkcjonowaniu kina. Nadszedł wreszcie wyczekiwany dzień przeprowadzenia losowania biletów przez szkoły. Na ulicach widać było szeregi matek z płaczącymi dziećmi, którym nie udało się wylosować biletu wstępu na przedstawienie. Przed moją kwaterą (mieszkaniem rodziny szkockiej, gdzie zostałem przydzielony) zbierały się grupy dzieci z matkami, licząc na możliwość uzyskania dodatkowych biletów. Na moje szczęście petentów tych załatwiali moi szkoccy gospodarze. Na końcu musiałem uzyskać zezwolenie władz państwowych, także ze względu na udział polskiego wojska w przedstawieniu. Otrzymałem je bez problemu, usłyszawszy przy tym wiele uprzejmości.

Kino Rio, z którego kierownikiem p. Walterem Hinksem byłem od czasu przybycia do Kirkcaldy w dobrych stosunkach, było obszerne i elegancko urządzone. Podłogi wyłożone były dywanami, a większość ścian pokryta została lustrami.

Impreza rozpoczęła się punktualnie o godz. 1419 grudnia 1940 r. i została poprzedzona słowem wstępnym, które wygłosił w języku polskim kapitan Jerzy Ciepielowski ${ }^{33}$. Było ono równocześnie tłumaczone na język angielski przez sierżanta

${ }^{32}$ Portret burmistrza Jamesa Wilsona autorstwa Alfreda Edwarda Borthwicka znajduje się w Kirkcaldy Galleries. Podczas II wojny światowej Wilson pełnił funkcję wiceprezesa Scottish-Polish Society.

${ }^{33}$ Kpt. Jerzy Marian Ciepielowski (1899-1969) - podczas II wojny awansował do stopnia majora i był jednym z 76 oficerów, których komunistyczna władza w Polsce 26 IX 1946 r. pozbawiła obywatelstwa polskiego. Nie mógł w tej sytuacji powrócić do Polski i musiał pozostać na terenie Wielkiej Bryta- 
Trypkę. Nawiązał on do toczącej się w Europie wojny oraz trudnej sytuacji dzieci polskich, które osamotnione spędzać będą święta w ciężkich warunkach okupacji niemieckiej. Następnie odsłonięto kurtynę i ukazała się Święta Rodzina na tle dużego świerkowego drzewka. Było ono nie tylko przystrojone m.in. w kolorowe łańcuchy oraz inne ozdoby, ale zawieszono na nim szkocką i polską flagę. U stóp drzewka umieszczono dużego białego orła, a tak skomponowaną prezentację strzegło dwóch aniołów - jedna Polka i jedna Szkotka. Wśród dzieci rozległy się głosy zdumienia i podziwu, gdyż one takiego widowiska nigdy nie widziały. Konferansjerkę w języku angielskim prowadziła p. Rybczyńska, która objaśniała pojawiające się na scenie różne symboliczne postacie. Najpierw ukazali się trzej królowie z darami, potem dwóch pasterzy z żywą owcą. Kolejno wystąpił polski żołnierz w mundurze z 1939 r. oraz kolejny żołnierz już we współczesnym mundurze brytyjskim. Cały korowód oddający hołd małemu Jezusowi (m.in. poprzebierani kolędnicy z gwiazdą i różnymi ozdobami) kończyło wystąpienie na scenie małego Szkota w ubiorze narodowym. Złożył on nowonarodzonemu w ofierze model samolotu z prośbą o opiekę nad lotnikami wszystkich narodowości broniącymi Wysp Brytyjskich. Ten ostatni występ wywołał zrozumiały entuzjazm wśród zgromadzonych.

W przerwach pomiędzy poszczególnymi występami nasz zaimprowizowany chór, umieszczony na scenie, śpiewał polskie kolędy dostosowane w swej treści do poszczególnych występów. Dużą atrakcją było wystąpienie na scenie diabła. Był nim młody, szczupły żołnierz ubrany w czarne trykoty z widocznymi na głowie różkami oraz ogonem. W rękach trzymał rózgę i łańcuch, który zaopatrzony był w dzwonki, którymi ciągle potrząsał. Miał też w masce pod oczyma parę lampeczek elektrycznych, które stale to świeciły się, to gasły, gdy on pędzony przez staruszka uganiał [się] po scenie. Pojawienie się diabła wśród dzieci siedzących pomiędzy rzędami krzeseł i jego harce wywołały wesołe okrzyki ze strony dzieci, gdyż była to dla nich niezwykła atrakcja.

Po jego wystąpieniu dzieci odśpiewały chórem kilka kolęd szkockich, tak, że ściany się niemal trzęsły - jak pisał szkocki sprawozdawca. Chórem dzieci kierował pan Hinks. Następnie pojawił się św. Mikołaj w towarzystwie kilku postaci ze sceny i żołnierzy niosących duże pudła zawierające torebki ze słodyczami, które rozdzielał dzieciom, idąc wzdłuż rzędów. Wreszcie na samym końcu jeden z kierowników szkół, pan Francis Binnie, złożył podziękowanie polskim władzom wojskowym, organizatorom i wykonawcom, a także p. Hinksowi i jego personelowi za tak piękne przygotowanie przedstawienia. Dzieci wzniosły trzy potężne okrzyki. Oczywiście, jak zawsze na terenie Wielkiej Brytanii, na zakończenie odśpiewano stojąc hymny brytyjski i polski, przy czym dzieci szkockie pomagały przy odśpiewaniu naszego hymnu.

Kiedy dzieci już wychodziły, przy wyjściu każde z nich otrzymało pamiątkowy obrazek przedstawiający polskiego żołnierza z książką pt. Poland i siedzącego obok szkockiego chłopca. Umieszczono na nim bardzo wymowny napis w języku

nii. K. Tarka, „Wrogowie” Polski. Pozbawienie obywatelstwa polskiego oficerów Polskich Sił Zbrojnych na Zachodzie, „Przegląd Historyczno-Wojskowy” 2013, nr 4, s. 65-84; idem, Pozbawienie polskiego obywatelstwa gen. Władysława Andersa i oficerów PSZ na Zachodzie, którzy wstapili do Polskiego Korpusu Przysposobienia i Rozmieszczenia [w:] Studia z dziejów Polskich Sit Zbrojnych na Zachodzie (1939-1947), red. P. Chmielowiec, K.A. Toch man, Warszawa-Rzeszów 2019, s. 205-216. 
angielskim pomiędzy flagami angielską i polską: Learn to know Poland and you shall love it as we love Scotland. Souvenir Christmas 1940 from Polish soldiers to Scottish children Kirkcaldy, który w języku polskim brzmi: „Naucz się poznawać Polskę, a pokochasz ją tak, jak my pokochaliśmy Szkocję. Pamiątka Święta Bożego Narodzenia ([ewentualnie:] bożenarodzeniowa) 1940 od polskich żołnierzy dla szkockich dzieci”. Jak napisał dziennikarz w „Dzienniku Polskim” ${ }^{34}$ wydawanym w Londynie z 8 styczna 1941 r., umieszczony na obrazku „chłopczyk w szkockiej spódniczce, nosi najbardziej chyba szkockie imię i nazwisko Duncan Stewart”. W niejednym domu w Kirkcaldy wisi on do dziś dnia na ścianie. Rozbawione dzieci na pożegnanie wznosiły okrzyki „Cheerioski”, zamiast szkockiego wyrażenia „Cheerio”. Stało się to dlatego, że sierżant Trypka, tłumaczący wygłaszane w języku polskim wystąpienia, objaśnił dzieciom, że ,jednym ze składników polskiej mowy jest końcówka ski, i że ich Cheerio po polsku powinno brzmieć cheerioski" ${ }^{35}$.

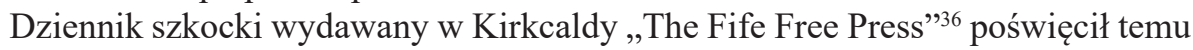
przedstawieniu najpierw czteroszpaltowy artykuł 21 grudnia z fotografią obrazka, zaś w następnym [numerze] z 28 grudnia 1940 r. zamieścił fotografię uczestników i organizatorów jasełek. Autor tego ostatniego artykułu opatrzył go - jak napisał najpopularniejszym polskim życzeniem świątecznym Szczesliwych Swiat, co szkocki dziennikarz przetłumaczył jako Happy World. Polski autor artykułu z londyńskiego „Dziennika Polskiego” zinterpretował ten drobny gramatyczny błąd jako „dobry prognostyk świąteczny najszybszego wywalczenia lepszego, szczęśliwszego świata" ${ }^{37}$. W odpowiedzi na pismo Dowództwa I Korpusu nr 2509/Prop[aganda] i Ośw[wiata] 40 z dnia 27 grudnia 1940 r. złożyłem na ręce Dowództwa O[oddziału] W[wydzielonego] 7. Brygady Kadrowej [Strzelców], Referat Kulturalno-Oświatowy $\mathrm{nr} 41$, dokładne sprawozdanie ze zorganizowanej imprezy pt. Wojsko polskie - dzieciom szkockim. 2 stycznia 1941 r. obszerny artykuł o wystawieniu polskich jasełek w Kirkcaldy zamieściło też czasopismo polskie wychodzące w Wielkiej Brytanii „Polska Walcząca - Żołnierz Polski na Obczyźnie”38. Podsumowując opis uroczystości, autor artykułu podpisujący się inicjałami A.J. napisał: „W nastroju ogólnej serdeczności i wzruszenia - skończył się - wieczór zorganizowany z ogromnym nakładem pracy i dużą miłością, przez polskich żołnierzy dla szkockich dzieci" ${ }^{39}$.

34 „Dziennik Polski” (Londyn) - pismo wydawane od VII 1940 r. przez Ministerstwo Informacji i Dokumentacji Rządu Polskiego na Uchodźstwie. J. Chwastyk-Kowalczyk, Londyński „Dziennik Polski" 1940-1943, Kielce 2005.

35 „Dziennik Polski” (Londyn), nr 152 z 8 I 1941 r.

${ }^{36}$ W rzeczywistości: tygodnik wychodzący w Kirkcaldy od $1871 \mathrm{r}$.

37 Ibidem, „The Fife Free Press” z 21 i 28 XII 1940 r.

38 „Polska Walcząca - Żołnierz Polski na Obczyźnie” - tygodnik (1939-1949) wydawany we Francji, a następnie w Wielkiej Brytanii pod redakcją Tymona Terleckiego przez Wydział Propagandy Ministerstwa Spraw Wojskowych.

39 „Polska Walcząca - Żołnierz Polski na Obczyźnie”, nr 3 z 18 I 1941 r. 


\section{ANEKS}
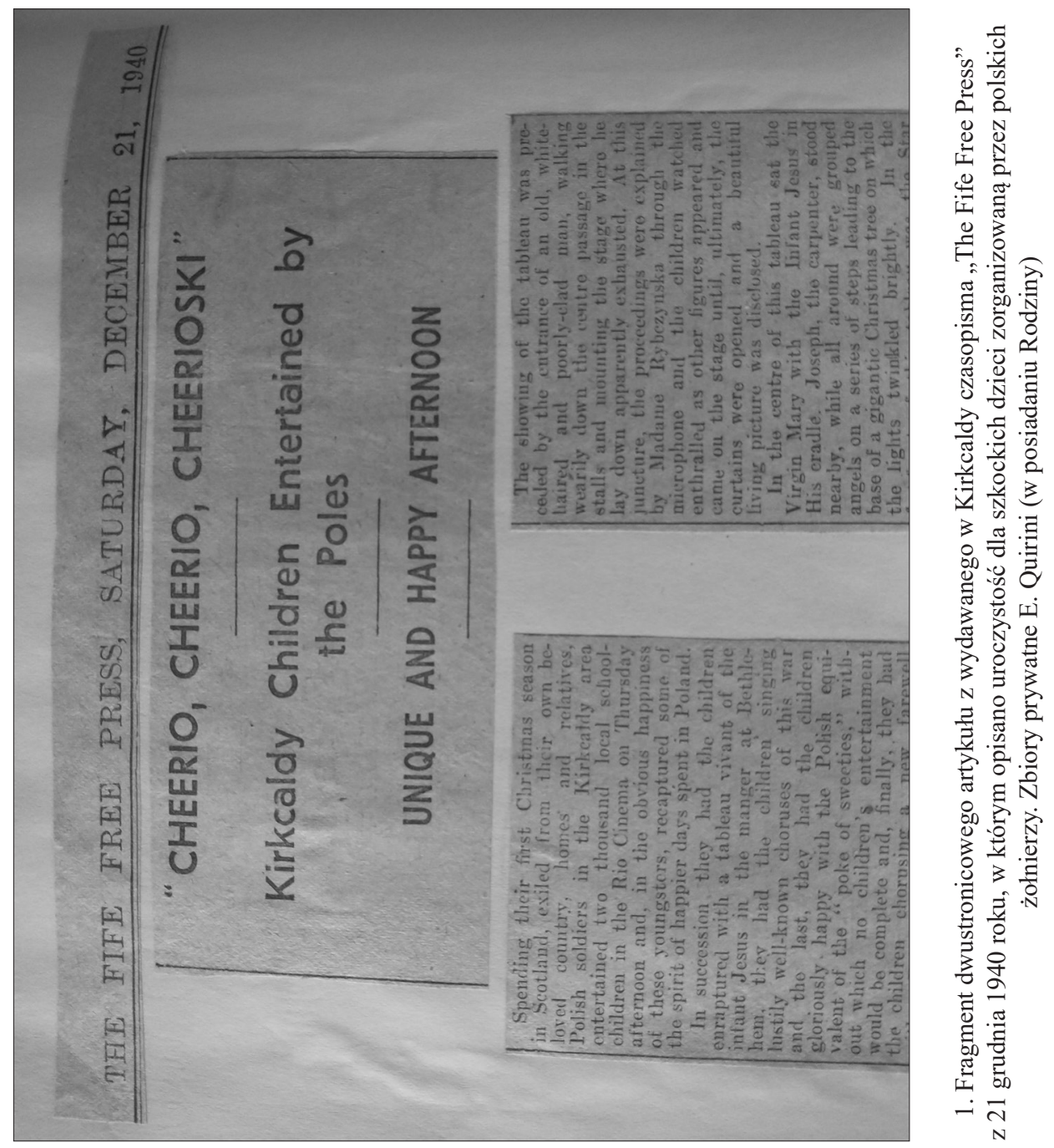

옥

क्षे है

它栲

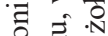

흔 릉

웡

근

졸

軍

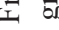

$-\bar{N}$ 


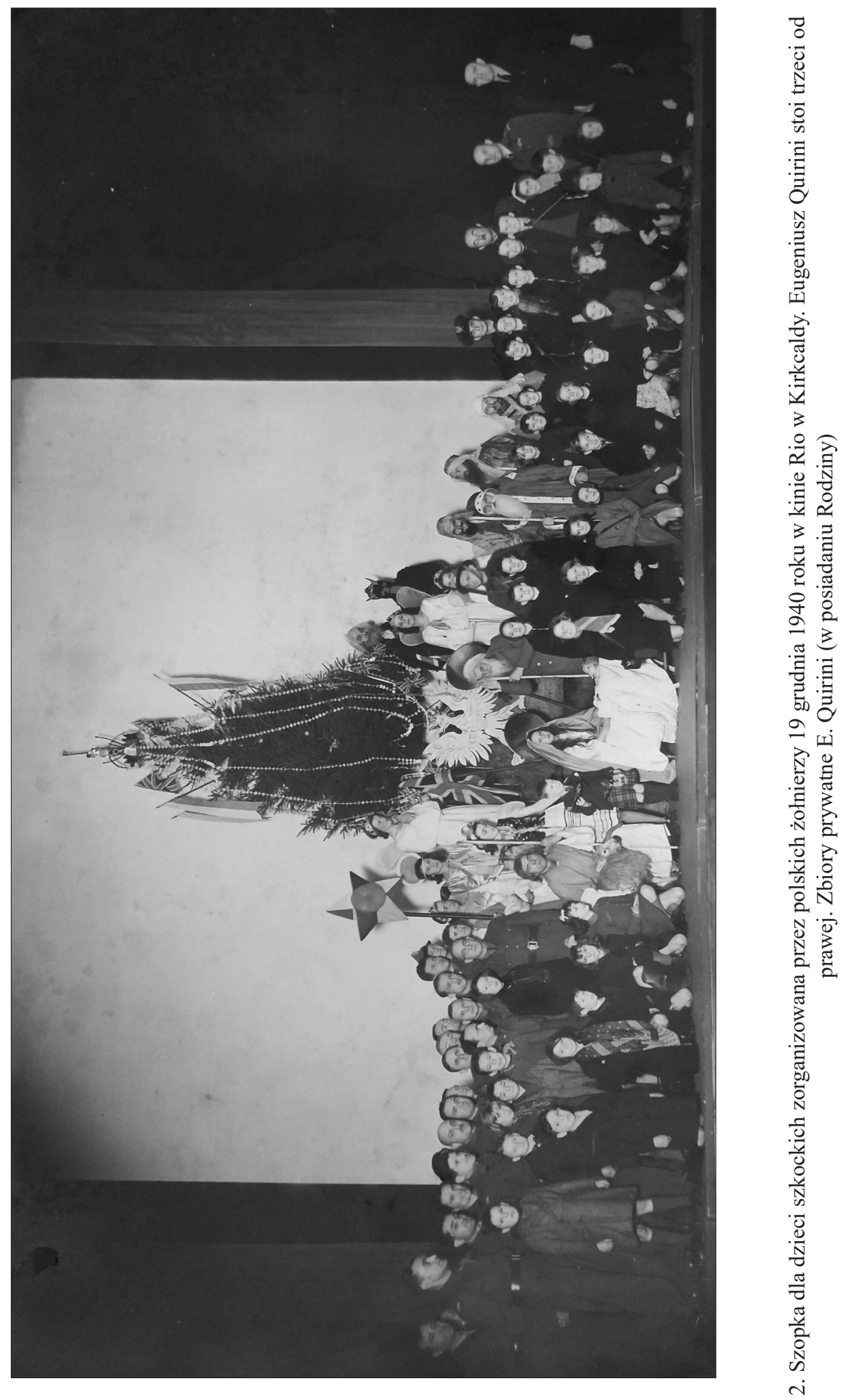




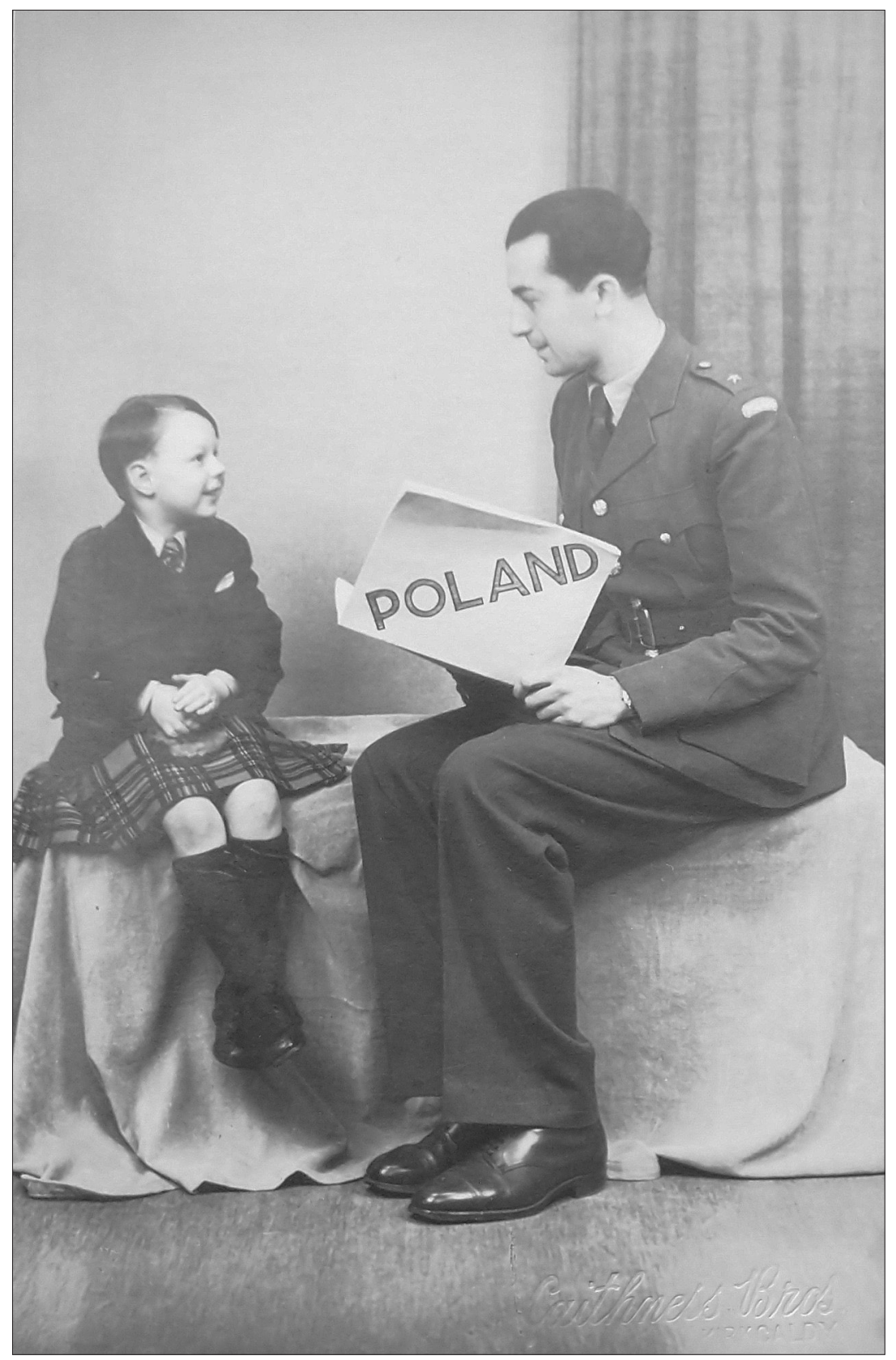

3. Fotografia przedstawiająca polskiego żołnierza z książką pt. Poland oraz siedzącego obok szkockiego chłopca. Lata 40. XX wieku 


\section{BIBLIOGRAFIA}

\section{Archiwalia}

Centralne Archiwum Wojskowe w Warszawie

AP 8, Wyciągi z rozkazów wewnętrznych m.in. Dowództwa Okręgu Korpusu II w Lublinie oraz listy kwalifikacyjne od 1924 do 1939 r.

Zbiory prywatne E. Quiriniego (w posiadaniu Rodziny)

Certificat (zaświadczenie) nr 3460 wydane przez Centre d'Hebergement pour les Militares Polonais a Paris (Stacja Zborna dla Żołnierzy Polskich w Paryżu), z dnia 1 stycznia $1940 \mathrm{r}$.

Polish „November Uprise” [sic!] 29 XI, 1830-1940 [program uroczystości]

Quirini E., Kalendarzyk Terminowy na rok 1939.

Quirini E., Zbiór materiałów: dokumentów, rysunków, kopii artykułów z prasy angielskiej i polskiej oraz fotografii w księdze pt. Poland and Scotland.

Anniversary celebration in „Rio Theatre” Kirkcaldy 8 XII 1940 [program uroczystości]

Zaświadczenie L. dz. 27/39 Szefa Propagandy Naczelnego Wodza ppłk. dypl. Romana Umiastowskiego, Warszawa, dnia 5 września 1939 r.

\section{Źródła opublikowane}

Armia Polska i życie spoleczne Polaków we Francji. Wrzesień 1939 - czerwiec 1940, wybór i oprac. M. Drozdowski, J. Smoliński, Warszawa 2001.

Marecki A., Jak korzystać z doświadczeń wojennych, „Bellona” 1940, R. XXII, z. 1., s. 3-7. Polskie Sity Zbrojne w drugiej wojnie światowej, t. II, Kompanie na obczyźnie, cz. I, Wrzesień 1939-czerwiec 1941, Londyn 1959.

Die Wehrmacht - Der Freiheitskampf des grossdeutschen Volkes, hrsg. von K. Fischer, Berlin 1940.

\section{Prasa}

„Dziennik Polski” (Londyn), nr 152 z 8 styczna 1941 r.

„The Fife Free Press" z 21 i 28 grudnia 1940 r.

„Polska Walcząca - Żołnierz Polski na Obczyźnie”, nr 3 z 18 stycznia 1941 r.

\section{Wspomnienia}

Strumph-Wojtkiewicz S., Wbrew rozkazowi. Wspomnienia oficera prasowego 19391945, Warszawa 1972. 


\section{Opracowania naukowe}

Biegański W., Finat dziwnej wojny. Studium o kampanii francuskiej 1940, Warszawa 1970.

Biegański W., Polskie Sity Zbrojne na Zachodzie 1939-1945, Warszawa 1990.

Biegański W., Wojsko Polskie we Francji 1939-1940, Warszawa 1967.

Biegański W., Zaczęło się w Coëtquidan, Warszawa 1977.

Bielak M., Ewakuacja żotnierzy polskich z Francji do Wielkiej Brytanii i Afryki Pótnocnej w latach 1940-1941 [w:] Letnia Szkota Historii Najnowszej, Warszawa 2009 (wersja elektroniczna w Bibliotece Cyfrowej IPN).

Bilek-Dąbrowska Z., Ligocki Edward [w:] Polski Słownik Biograficzny, t. 17, Warszawa 1972, s. 323-325.

Chwastyk-Kowalczyk J., Londyński „,Dziennik Polski” 1940-1943, Kielce 2005.

Historia dyplomacji polskiej, t. 5, 1939-1945, red. W. Michowicz, Warszawa 1999.

Hułas M., Goście czy intruzi? Rząd polski na uchodźstwie wrzesień 1939-lipiec 1943, Warszawa 1996.

Kania L., Stużba Sprawiedliwości Wojska Polskiego we Francji i w Wielkiej Brytanii (październik 1939-październik 1940), „Przegląd Historyczno-Wojskowy” 2014, t. 15 (66), s. 67-96.

Komornicki S., Bielecki Z., Bigoszewska W., Jońca A., Wojsko Polskie 1939-1945. Barwa i Broń, Warszawa 1984.

Korczyk H., Quirini de Saalbrück Eugeniusz [w:] Polski Słownik Biograficzny, t. 29, Wrocław-Warszawa-Kraków-Gdańsk-Lódź 1986, s. 532.

Krotofil M., Wojsko polskie w Szkocji podczas II wojny światowej [w:] Sity Zbrojne RP. Wybrane zagadnienia, red. M. Krotofil, R. Rybak, Torun 2019.

Peszke M., Polskie Siły Zbrojne na Zachodzie 1939-1946, Poznań 2014.

Smoliński J., Działalność naczelnych władz wojskowych podczas ewakuacji wojska polskiego do Wielkiej Brytanii w czerwcu 1940 r., „Niepodległość i Pamięć” 1999, nr 6/2 (15), s. 213-228.

Smoliński J., Ewakuacja Wojska Polskiego do Wielkiej Brytanii w czerwcu 1940, Warszawa 1996.

Smoliński J., Koncepcje formowania i użycia Wojska Polskiego we Francji (wrzesień 1939-czerwiec 1940), „Niepodległość i Pamięć” 2017, nr 2(58), s. 151-173.

Smoliński J., Lwowska Fala na wojennym szlaku (1939-1946), red. nauk. J. Gmitruk, T. Skoczek, Warszawa 2021.

Smolińs ki J., Polskie Sity Zbrojne na Zachodzie 1939-1945, Warszawa 1997.

Smoliński J., Wysitek wojenny Polskich Sit Zbrojnych na Zachodzie (1939-1945), „Niepodległość i Pamięć” 2019, 26, nr 4 (68), s. 91-125.

Szczurowski M., Geneza formowania Armii Polskiej we Francji 1939-1940, „Piotrkowskie Zeszyty Historyczne” 2002, t. 4., s. 115-143.

Tarka K., Pozbawienie polskiego obywatelstwa gen. Władysława Andersa i oficerów PSZ na Zachodzie, którzy wstapili do Polskiego Korpusu Przysposobienia i Rozmieszczenia [w:] Studia z dziejów Polskich Sił Zbrojnych na Zachodzie (1939-1947), red. P. Chmielowiec, K.A. Tochman, Warszawa-Rzeszów 2019.

Tarka K., „,Wrogowie” Polski. Pozbawienie obywatelstwa polskiego oficerów Polskich Sit Zbrojnych na Zachodzie, „Przegląd Historyczno-Wojskowy” 2013, nr 4, s. 65-84.

Wawer Z., Polskie Sity Zbrojne na obczyźnie [w:] Polski wiek XX: II wojna światowa, Warszawa 2010.

Zuziak J., Wysiłek mobilizacyjno-organizacyjny Polskich Sit Zbrojnych na Zachodzie w drugiej wojnie światowej, „Piotrkowskie Zeszyty Historyczne” 2003, t. 5, s. 235-246. 


\section{Wydawnictwa popularnonaukowe}

Terlecki O., Generat Sikorski, Kraków 1981.

\section{Netografia}

Biography of 'Hinks Walter', https://movingimage.nls.uk/biography/10017 [dostęp: 6 VII 2020 r.].

Kania L., Dylematy wojskowej Temidy, https://pk.gov.pl/wp-content/uploads/2016/07/a9be4a06bd6354fd3d926d1330949802.pdf [dostęp: 23 IV 2020 r.].

Miśkiewicz B., Wojsko Polskie na tle europejskim, http://www.wbc.poznan.pl/Content/39738/PDF/Wojsko\%20Polskie\%20na\%20tle\%20europejskim..pdf [dostęp: 5 IX 2020 r.].

Władysław Sikorski (1881-1943), https://dzieje.pl/postacie/wladislaw-sikorski [dostęp: 2 V 2020 r.]. 